\title{
Optimization of the Microstructure and Mechanical Properties of a Laves Phase-Strengthened Hypoeutectic NiAl/Cr(Mo,W) Alloy by Suction Casting
}

\author{
L. Y. Sheng, ${ }^{\text {a,1 }}$ B. N. Du, ${ }^{\text {a }}$ S. P. Zan, ${ }^{\text {b C. Lai }},{ }^{a}$ J. K. Jiao, ${ }^{b}$ Y. B. Gao, ${ }^{c}$ and T. F. Xi ${ }^{a}$ \\ ${ }^{a}$ Shenzhen Institute, Peking University, Shenzhen, China \\ ${ }^{\mathrm{b}}$ Ningbo Institute of Materials Technology and Engineering, Chinese Academy of Sciences, Ningbo, \\ China \\ ${ }^{c}$ Department of Stomatology, Longgang District Central Hospital, Affiliated to Zunyi Medical \\ College, Shenzhen, Guangdong, China \\ ${ }^{1}$ lysheng@yeah.net
}

УДК 539.4

\section{Оптимізація мікроструктури і механічних властивостей доевтектичного сплаву $\mathrm{NiAl} / \mathrm{Cr}(\mathrm{Mo}, \mathrm{W})$, зміцненого фазою Лавеса, при литті методом вакуумного всмоктування}

\author{
Л. Й. Шенга ${ }^{a}$ Б. Н. Ду ${ }^{a}$ С. П. Зан ${ }^{\sigma}$, Ц. Лайа ${ }^{a}$ Д. К. Жиао ${ }^{\sigma}$ Й. Б. Гао \\ a Шеньчженьський інститут Пекінського університету, Шеньчжень, Китай \\ ${ }^{\sigma}$ Інститут технології матеріалів і машинобудування, Китайськя академія наук, Нінбо, Китай \\ ${ }^{\text {в } Ц е н т р а л ь н а ~ л і к а р н я ~ о к р у г а ~ Л о н г г а н, ~ Ш е н ь ч ж е н ь, ~ К и т а и ̆ ~}$
}

Отримано легований ніобісм (Nb) доевтектичний сплав $\mathrm{NiAl/Cr}(\mathrm{Mo}, W)$ nри звичайному литті $i$ литті методом вакуумного всмоктування. Вивчено його мікроструктура і механічні властивості при стиску для оцінки впливу процесу виробництва. Показано, щчо велика первинна фаза $\mathrm{NiAl}$ і евтектична комірка $\mathrm{NiAl/Cr}(\mathrm{Mo})$ є основними компонентами сплаву $\mathrm{NiAl} / \mathrm{Cr}(\mathrm{Mo}, \mathrm{W})-\mathrm{Nb}$. Введення $\mathrm{Nb}$ зумовлюе виникнення фази Лавеса по межі евтектичної комірки. Лиття методом вакуумного всмоктування суттєво поліпшує стан евтектичної комірки $\mathrm{NiAl/Cr}(\mathrm{Mo})$, первинної фази $\mathrm{NiAl}$, евтектичної ламелі, міжккомірчастої області $і$ фази Лавеса $\mathrm{Cr}_{2} \mathrm{Nb}$, забезпечує рівномірний розподіл останньої та підвищує розчинність сплаву в твердому стані. За кімнатної температури граниия плинності ливарного сплаву, отриманого методом вакуумного всмоктування, сягає 1495 МПа, опір стиску - 2030 МПа, пластичність - 30\%, щзо приблизно на 50, 30 і 100\% відповідно вище за аналогічні показники звичайного ливарного сплаву. Суттєве поліпшення механічних властивостей за кімнатної температури може бути зумовлено оптимізацією мікроструктури при литті методом вакуумного всмоктування. При 1273 К механічні властивості сплаву майже такі ж, щзо головним чином пов'язано зі збільшенням міжкомірчастої області.

Ключові слова: лиття методом вакуумного всмоктування, фаза Лавеса, мікроструктура, доевтектичний сплав $\mathrm{NiAl} / \mathrm{Cr}(\mathrm{Mo}, \mathrm{W})$, механічні властивості.

Introduction. Recently, Ni-based intermetallic compounds have been paid much attention, due to its high melting point, special interfacial chemical properties, and good environment tolerance [1-3]. As a kind of intermetallic compound, NiAl owns many attractive advantages such as high melting point, excellent oxidation and corrosion resistance, relative low density, good thermal conductivity etc [4-6]. Therefore, it has been thought as the potential candidate for high temperature structure materials subjected to the severe oxidation and corrosion [7, 8]. According to previous researches [9, 10], NiAl has 
long-range ordered crystal structure, which enhances its strength but results in the brittleness at low temperature. Such a dependence of mechanical properties on temperature handicaps the application of $\mathrm{NiAl}$ as the structural parts suffering loading and corrosion [11-13]. However, the excellent oxidation and corrosion resistance of NiAl still makes it to be qualified as the protecting shield or fixed part [14]. Whatever, these applications also require that $\mathrm{NiAl}$ should have certain strength and deformability. Therefore, improving mechanical properties of NiAl or its alloys becomes necessary.

In order to improve mechanical properties of NiAl, lots of methods have been applied and so many NiAl based materials have been designed and fabricated [15-18]. Yang et al. [19] fabricated the $\mathrm{NiAl} / \mathrm{Cr}(\mathrm{Mo})$ eutectic alloy and investigated its deformation mechanism which indicates the appropriate $\mathrm{Cr}(\mathrm{Mo})$ and $\mathrm{NiAl}$ lamellar structure was beneficial to mechanical properties. However, compared with the superalloy, the strength and fracture toughness of the $\mathrm{NiAl} / \mathrm{Cr}(\mathrm{Mo})$ eutectic alloy still need great improvement [20]. To enhance strength of the $\mathrm{NiAl} / \mathrm{Cr}(\mathrm{Mo})$ eutectic alloy, strengthening particles are introduced. Cui et al. [21] prepared the $\mathrm{NiAl} / \mathrm{Cr}(\mathrm{Mo})$ eutectic alloy strengthened by Heusler phase and improved strength of the alloy obviously, but the segregation of Heusler phase along boundary is detrimental to the deformability. Sheng et al. [22] exhibited that Laves phase would improve strength of the $\mathrm{NiAl} / \mathrm{Cr}(\mathrm{Mo})$ eutectic alloy, but this strengthening phase preferred to aggregate in intercellular region and decreased compressive ductility. Recent researches [23-25] on the rapid solidification reveals that it could promote microstructure refinement and restrict element segregation, which could be used to optimize microstructure and mechanical properties of the $\mathrm{NiAl} / \mathrm{Cr}(\mathrm{Mo})$ eutectic alloy. In addition, the recent researches [26-28] on the Laves phase revealed that it would generate stacking faults during the deformation, which might cooperate with the deforming of the eutectic alloy and beneficial to the mechanical properties. Furthermore, the former researches [29] exhibited that the high solidification rate would promote the growth of eutectic structure and restrict the formation of primary phase. Moreover, few research had been carried out on rapidly solidified $\mathrm{NiAl} / \mathrm{Cr}(\mathrm{Mo})$ hypoeutectic alloy strengthened by Laves phase. Therefore, in the present research minor $\mathrm{Nb}$ and $\mathrm{W}$ were added in $\mathrm{NiAl} / \mathrm{Cr}(\mathrm{Mo})$ hypoeutectic alloy to form Laves phase and strengthen $\mathrm{Cr}(\mathrm{Mo})$ phase, respectively. Moreover, conventional casting (CC) and suction casting (SC) were applied to prepare the $\mathrm{NiAl} / \mathrm{Cr}(\mathrm{Mo}, \mathrm{W})-\mathrm{Nb}$ hypoeutectic alloy. The microstructure evolution and mechanical properties of the hypoeutectic alloys by different methods were studied simultaneously.

1. Experimental Procedure. Pure chromium (99.9\%), tungsten (99.8\%), nickel (99.9\%), niobium (99.8\%), aluminum (99.9\%), and molybdenum (99.8\%) were used as raw materials to fabricate the $\mathrm{NiAl} / \mathrm{Cr}(\mathrm{Mo}, \mathrm{W})-\mathrm{Nb}$ hypoeutectic alloy with chemical composition of $\mathrm{Ni}-33 \mathrm{Al}-28 \mathrm{Cr}-5 \mathrm{Mo}-0.5 \mathrm{Nb}-0.5 \mathrm{~W}$ (at.\%) by induction melting. During the induction melting of the alloy, the ceramic shell was heated to $973 \mathrm{~K}$, and then the melted alloy was poured into the ceramic shell to get as-cast rods $(\varnothing 50 \times 200 \mathrm{~mm})$. The as-cast rods obtained by $\mathrm{CC}$ were cut into small samples. Some samples were studied at as-cast state and other samples were crushed for SC. The SC was performed by the water-cooled copper mold technique, which was applied to fabricate the amorphous material. The crushed alloy was remelted under high vacuum in a quartz tube by using induction heating coil and sucked into the $\mathrm{Cu}$ mold with a cavity of $10 \mathrm{~mm}$ diameter.

Specimens for compressive properties testing and microstructure observation were cut from the CC and SC samples. Phenom ${ }^{\mathrm{TM}}$ Pro and S-3400 scanning electron microscopes (SEM) were used to carry out microstructure observation. The resultant phases in the hypoeutectic alloy were studied by X-ray diffraction (XRD) with a $\mathrm{Cu}$ radiation at $40 \mathrm{kV}$ and $40 \mathrm{~mA}$. The Chemical compositions of different phases in the $\mathrm{CC}$ and SC alloys were analyzed by EPMA-1610 electronic probe microanalysis (EPMA). The observation on precipitates and crystal defects were performed on the JEOL-2010 transmission electron microscope (TEM). The slices with $0.4 \mathrm{~mm}$ thickness were cut from $\mathrm{CC}$ and SC samples 
to prepare TEM specimens. The slice was polished to $30 \mu \mathrm{m}$ and shaped into $\varnothing 3 \mathrm{~mm}$ followed by twin-jet electropolishing in a solution of $90 \%$ alcohol and $10 \%$ perchloric acid at $-20^{\circ} \mathrm{C}$. During the twin-jet electropolishing, the twin-jet current is maintained at $40 \mathrm{~mA}$. The samples $(4 \times 4 \times 6 \mathrm{~mm})$ for compression test were cut from the $\mathrm{CC}$ and $\mathrm{SC}$ alloy samples and mechanically grounded by 1000 -grit $\mathrm{SiC}$ abrasive. Compression test was performed on the Gleeble 3800 with the initial strain rate of $2 \cdot 10^{-3} \mathrm{~s}^{-1}$ at room temperature and $1273 \mathrm{~K}$.

\section{Results and Discussion.}

2.1. Microstructure. Typical microstructure of the $\mathrm{CC} \mathrm{NiAl} / \mathrm{Cr}(\mathrm{Mo}, \mathrm{W})-\mathrm{Nb}$ hypoeutectic alloy observed by SEM are exhibited in Fig. 1. Obviously, black primary NiAl phase, $\mathrm{NiAl} / \mathrm{Cr}(\mathrm{Mo})$ eutectic structure and white Laves phase are the main constituents of the alloy, as shown in Fig. 1a. Moreover, the microstructure of hypoeutectic alloy could be distinguished into eutectic cell and intercellular region. In eutectic cell, the gray $\mathrm{Cr}(\mathrm{Mo})$ and black NiAl lamella grow from center to boundary, as shown in Fig. 1b. The statistical analyses on the eutectic cell exhibit that the sizes of eutectic cell and primary NiAl phase are 100-200 and 20-50 $\mu \mathrm{m}$, respectively. The average thickness of lamella in eutectic cell is approximately $4 \mu \mathrm{m}$. Along the eutectic cell boundary, white Laves phase, coarser primary $\mathrm{NiAl}$ phase and bulk $\mathrm{Cr}(\mathrm{Mo})$ phase comprise the intercellular region. In addition, it also can find that there are NiAl precipitates in $\mathrm{Cr}(\mathrm{Mo})$ phase and $\mathrm{Cr}(\mathrm{Mo})$ precipitates in $\mathrm{NiAl}$ phase, which may be attributed to the intergrowth of $\mathrm{Cr}(\mathrm{Mo})$ and $\mathrm{NiAl}$ and incomplete element diffusion.
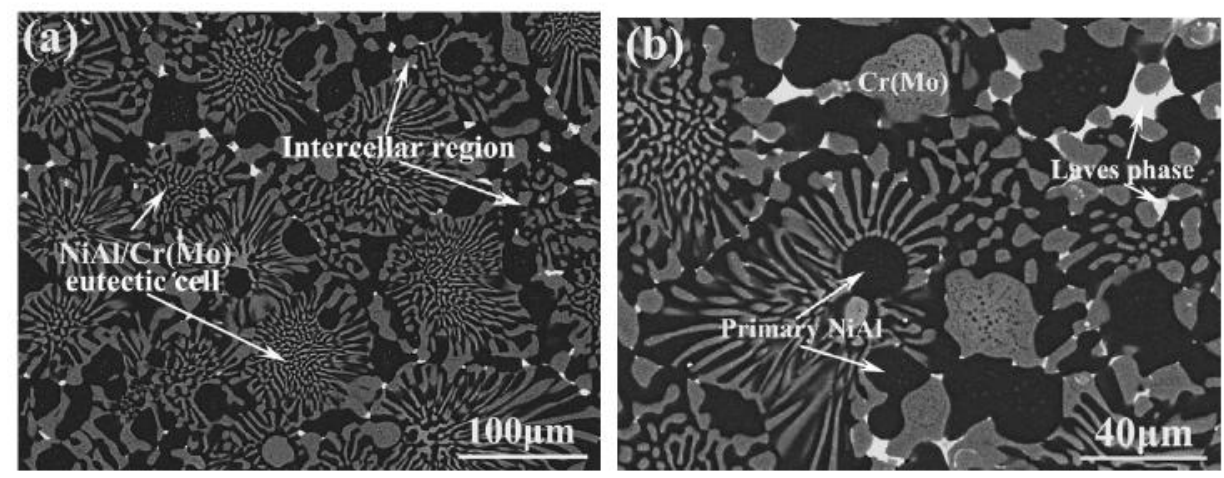

Fig. 1. (a) SEM micrograph of the $\mathrm{CC} \mathrm{NiAl/Cr}(\mathrm{Mo}, \mathrm{W})-\mathrm{Nb}$ hypoeutectic alloy; (b) morphology of eutectic structure and precipitates.

The XRD analysis is carried out to confirm the phase precipitation in the CC $\mathrm{NiAl} / \mathrm{Cr}(\mathrm{Mo}, \mathrm{W})-\mathrm{Nb}$ hypoeutectic alloy. The result of the XRD analysis is shown in Fig. 2. It confirms that $\mathrm{Cr}(\mathrm{Mo})$ and $\mathrm{NiAl}$ phases are the main constituent phases. $\mathrm{The} \mathrm{Cr}(\mathrm{Mo})$ phase along (110) and (211) crystal plane exhibits strong diffraction peak, which indicate the $\mathrm{Cr}(\mathrm{Mo})$ phase prefer to grow along these crystal planes. The NiAl phase exhibits the strongest diffraction peak along (110) crystal plane. What is interesting is the NiAl and $\mathrm{Cr}(\mathrm{Mo})$ phases exhibit growth preference along (211) crystal plane. According to the previous researches $[22,30]$, such a phenomenon may be attributed to the addition of $\mathrm{W}$ and $\mathrm{Nb}$, which increases the nucleation cores and influences the crystal growth. Though the small addition of $\mathrm{Nb}$ could not generate a lot of Laves phase, the precipitation of Laves phase along phase boundary also influences the crystal growth.

To characterize the precipitates in the hypoeutectic alloy further, TEM analysis is performed on the $\mathrm{CC} \mathrm{NiAl} / \mathrm{Cr}(\mathrm{Mo}, \mathrm{W})-\mathrm{Nb}$ hypoeutectic alloy and the results are shown in Fig. 3. The Laves phase with irregular shape is precipitated along $\mathrm{NiAl} / \mathrm{Cr}(\mathrm{Mo})$ phase boundary, as shown in Fig. 3a. According to the inset selected area electron diffraction 


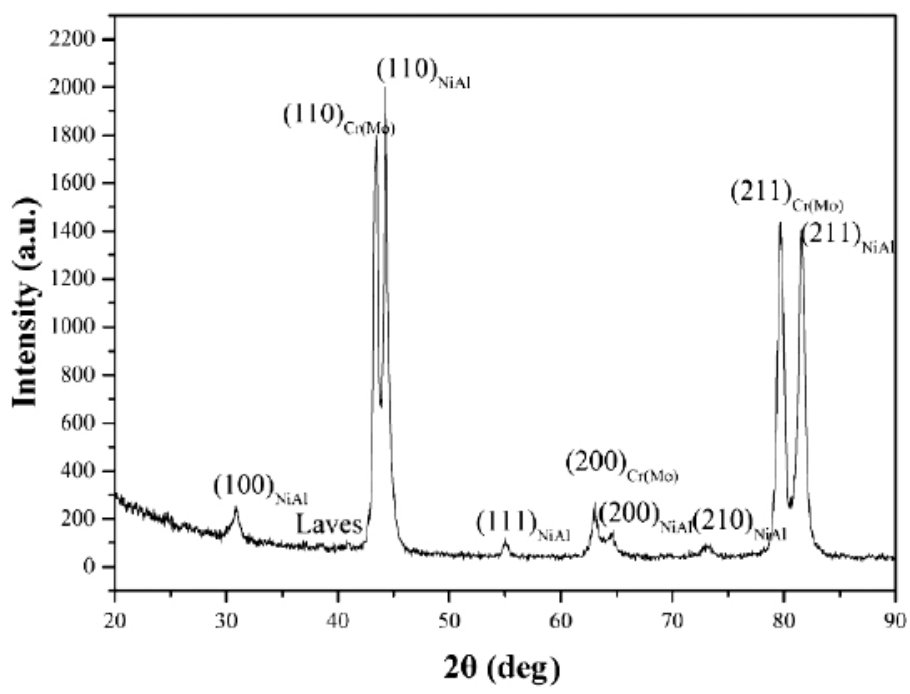

Fig. 2. XRD pattern of the $\mathrm{CC} \mathrm{NiAl/Cr}(\mathrm{Mo}, \mathrm{W})-\mathrm{Nb}$ hypoeutectic alloy.
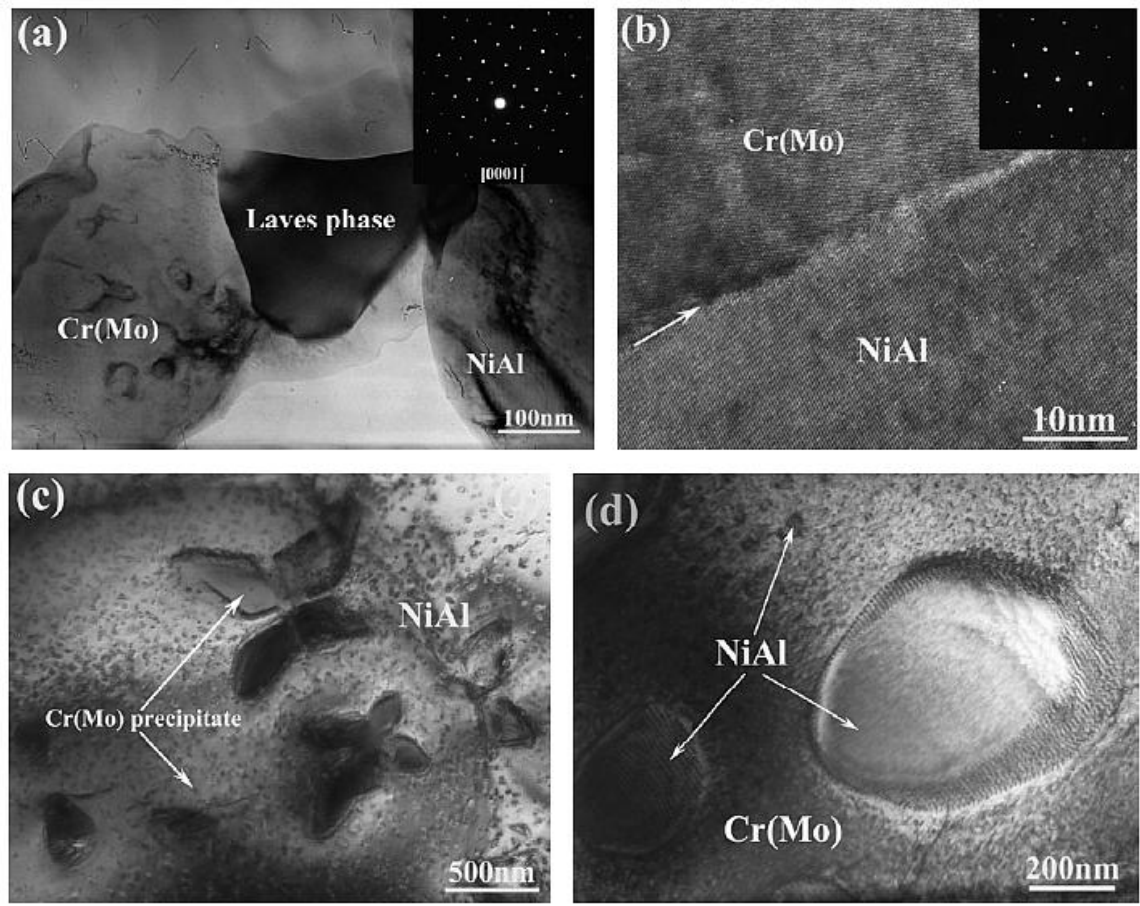

Fig. 3. (a) TEM micrograph of $\mathrm{Cr}_{2} \mathrm{Nb}$ Laves phase (inset image showing the SAED pattern of Laves phase); (b) HRTEM of NiAl/Cr(Mo) phase interface [inset image showing SAED pattern of NiAl and $\mathrm{Cr}(\mathrm{Mo})$ phases]; (c) TEM micrograph of $\mathrm{Cr}(\mathrm{Mo})$ precipitates with butterfly and sphere shape; (d) TEM micrograph of $\mathrm{NiAl}$ precipitate and interface dislocations.

(SAED) pattern along [0001] zone axis, it confirms that the Laves phase is $\mathrm{Cr}_{2} \mathrm{Nb}$ and possesses the hexagonal crystal lattice $(a=b=0.487 \mathrm{~nm}$ and $c=0.794 \mathrm{~nm})$ with space group of $\mathrm{P} 63 / \mathrm{mmc}$. Moreover, it proves that the $\mathrm{Cr} 2 \mathrm{Nb}$ Laves phase has $\mathrm{C} 14$ crystal structure. According to the recent studies $[22,28]$, the existence of $\mathrm{Al}$ and $\mathrm{Ni}$ in Laves 
phase is beneficial to stabilize the $\mathrm{C} 14$ crystal structure at low temperature. Moreover, TEM observation on the $\mathrm{Cr}_{2} \mathrm{Nb}$ Laves phase has not found any stacking fault. Further TEM observation on phase boundary of $\mathrm{NiAl} / \mathrm{Cr}(\mathrm{Mo})$ eutectic lamella shows that it has no precipitates and exhibits clear and straight shape, as shown in Fig. 3b. Additionally, TEM observation on NiAl phase finds $\mathrm{Cr}(\mathrm{Mo})$ precipitates have two sizes, as shown in Fig. 3c. The first one has big size $(200-600 \mathrm{~nm})$ and constitutes the butterfly shape, while the other has small size of about $20 \mathrm{~nm}$ and exhibits a sphere shape. The presence of big $\mathrm{Cr}(\mathrm{Mo})$ precipitates should be ascribed to the heat of ceramic shell which extends the solidification time and benefits the growth of precipitates. TEM observations on $\mathrm{Cr}(\mathrm{Mo})$ phase exhibit that all NiAl precipitates exhibit the sphere shape but there are two sizes, as shown in Fig. 3d. The big one is more than $600 \mathrm{~nm}$ and the small one is about $20 \mathrm{~nm}$. The abundant interface dislocations can be found in NiAl precipitate or along its boundary.

SEM observation on the SC NiAl/Cr(Mo,W)-Nb hypoeutectic alloy is shown in Fig. 4. Obviously, microstructure of the hypoeutectic alloy has been changed by the suction casting greatly. The primary NiAl becomes fine and its morphology exhibits dendritic feature, as shown in Fig. 4a. The statistical analysis on the SC hypoeutectic alloy exhibits the size of primary NiAl phase is $5-20 \mu \mathrm{m}$ and the eutectic cell size is $10-60 \mu \mathrm{m}$, which is smaller than those of the CC hypoeutectic alloy. By comparing with the CC and SC hypoeutectic alloys, it can find the SC decreases the primary NiAl a little but bulk NiAl phase greatly. Moreover, the $\mathrm{NiAl} / \mathrm{Cr}(\mathrm{Mo})$ eutectic lamella in the $\mathrm{SC}$ hypoeutectic alloy becomes more uniform and the intercellular region becomes fine. The statistical analysis on the eutectic lamella exhibits $\mathrm{NiAl} / \mathrm{Cr}(\mathrm{Mo})$ lamella in eutectic cell of about $1 \mu \mathrm{m}$ but that in the intercellular region it is about $3 \mu \mathrm{m}$. Except the regular spherical primary $\mathrm{NiAl}$, the ellipsoid primary NiAl merges into flower structure, as shown in Fig. 4b. The merging of primary NiAl results in the expanding of eutectic cell, leading to bigger structures. The foremost evolution is that the Laves phase becomes fine and distributes uniformly. In addition, there are some Laves phases precipitated in the primary NiAl, which confirms that the $\mathrm{Nb}$ addition would increase the nucleation.
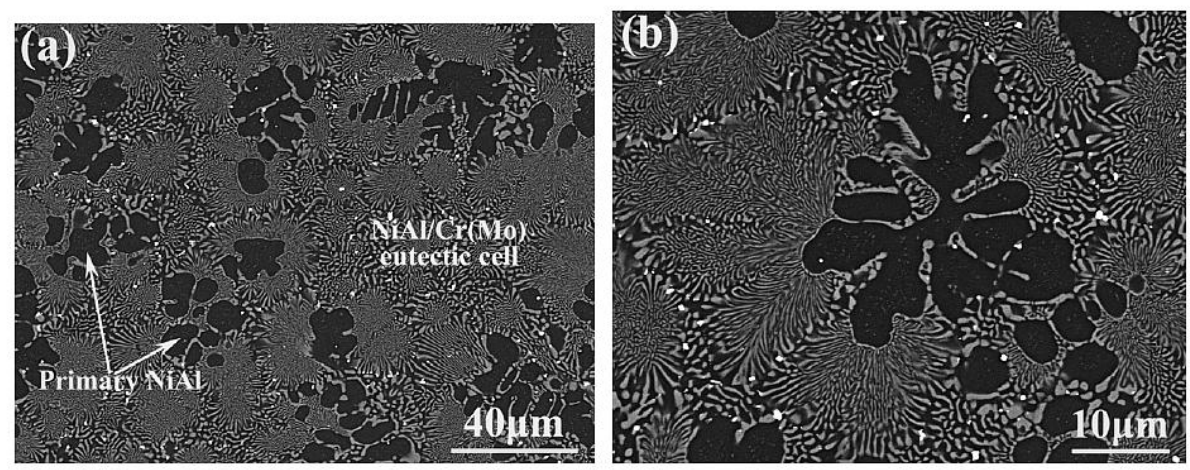

Fig. 4. (a) SEM micrograph of the SC NiAl/Cr(Mo,W)-Nb hypoeutectic alloy; (b) morphology of the eutectic structure and precipitates.

To investigate the detailed microstructure evolution, TEM observation is carried out on the SC alloy, as shown in Fig. 5. It is evident that along the primary NiAl phase boundary, the $\mathrm{NiAl} / \mathrm{Cr}(\mathrm{Mo})$ eutectic structure exhibits ultrafine size, as shown in Fig. 5a. Moreover, $\mathrm{Cr}(\mathrm{Mo})$ phase has formed a continuous film along the primary NiAl interface, which indicates the $\mathrm{Cr}(\mathrm{Mo})$ phase film is formed instantaneously. Based on the recent investigation [31], the intergrowth of eutectic structure needs rapid interdiffusion of composition between the eutectic phases. The deviation of the composition from eutectic in the present research promotes the prior precipitation of $\mathrm{NiAl}$ and then results in the 

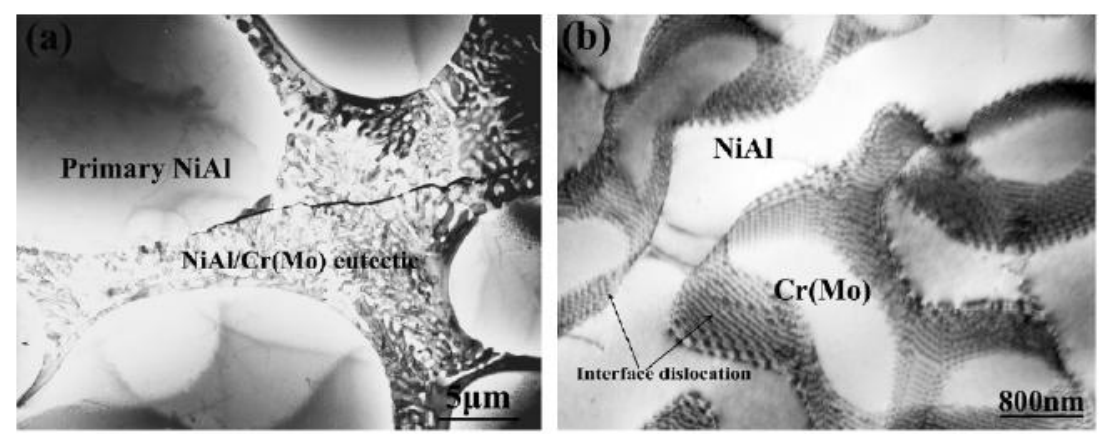

Fig. 5. (a) TEM micrograph of the ultrafine $\mathrm{NiAl} / \mathrm{Cr}(\mathrm{Mo})$ eutectic structure; (b) TEM micrograph of interface dislocations along $\mathrm{NiAl} / \mathrm{Cr}(\mathrm{Mo})$ phase interface.

rejection of $\mathrm{Cr}$ and $\mathrm{Mo}$ elements along solid/liquid interface. The segregated $\mathrm{Cr}$ and $\mathrm{Mo}$ could enhance the constitutional supercooling before the solid/liquid interface, which increases the growth rate of $\mathrm{NiAl} / \mathrm{Cr}(\mathrm{Mo})$ eutectic and refines it at the initial growth stage. The observation on $\mathrm{NiAl} / \mathrm{Cr}(\mathrm{Mo})$ eutectic lamella exhibits plentiful interface dislocations distributed along phase interface, as shown in Fig. 5b. The width range of interface dislocation is $80-1100 \mathrm{~nm}$. Based on the previous studies [22, 24], the formation of abundant interface dislocations should be ascribed to the increased solid solution elements resulted by the suction casting.

To study the influence of the rapid solidification, the composition of constituent phases in the CC and SC hypoeutectic alloys are analyzed. As shown in Table 1, the suction casting restricts the diffusion of elements, so the amount of solid solute in the phase over exceeds its solid solubility greatly. The primary NiAl phase contains $6.86 \% \mathrm{Cr}$ in the $\mathrm{SC}$ hypoeutectic alloy and it is about three times that in the $\mathrm{CC}$ hypoeutectic alloy. Moreover, the $\mathrm{Ni}, \mathrm{Al}$ content of $\mathrm{Cr}(\mathrm{Mo})$ phase in the $\mathrm{SC}$ hypoeutectic alloy is about two times that in the CC hypoeutectic alloy. However, the solid solute in the Laves phase has not changed greatly in the SC hypoeutectic alloy, compared with the $\mathrm{CC}$ hypoeutectic alloy. Based on the above observation, the primary NiAl phase has small precipitate in SC alloy. More solid solute $\mathrm{Cr}$ in primary $\mathrm{NiAl}$ phase of the $\mathrm{SC}$ hypoeutectic alloy would increase the lattice distortion and strength [30]. Such elements distribution in the CC and SC hypoeutectic alloys should be ascribed to the eutectic structure partly. During the solidification, the high cooling rate could provide great supercooling, which increases the nucleation rate and restricts interdiffusion between the $\mathrm{Cr}(\mathrm{Mo})$ and NiAl phase. Thus more heterogeneous elements would be rejected along eutectic phase boundary. Therefore, the lattice distortion along the $\mathrm{NiAl} / \mathrm{Cr}(\mathrm{Mo})$ phase boundary would be greater than that in phase, which results in abundant interface dislocation. Due to the similar precipitation of big NiAl particles in $\mathrm{Cr}(\mathrm{Mo})$ phase, it also has a lot of interface dislocations.

T a b 1 e 1

Chemical Composition of Constituent Phases in the CC and SC Hypoeutectic Alloys (at.\%)

\begin{tabular}{|c|c|c|c|c|c|c|c||}
\hline \hline Alloy & Phase & $\mathrm{Al}$ & $\mathrm{Ni}$ & $\mathrm{Cr}$ & $\mathrm{Mo}$ & $\mathrm{W}$ & $\mathrm{Nb}$ \\
\hline \multirow{3}{*}{$\mathrm{CC}$} & Primary NiAl & 50.21 & 47.34 & 2.30 & 0.15 & - & - \\
\cline { 2 - 8 } & $\mathrm{Cr}(\mathrm{Mo})$ & 3.80 & 2.90 & 80.78 & 10.86 & 1.46 & 0.20 \\
\cline { 2 - 8 } & Laves & 11.10 & 15.20 & 36.48 & 7.64 & 0.82 & 28.76 \\
\hline \multirow{3}{*}{ SC } & Primary NiAl & 46.96 & 45.36 & 6.86 & 0.82 & - & - \\
\cline { 2 - 8 } & Cr(Mo) & 9.60 & 8.60 & 68.18 & 10.32 & 2.84 & 0.46 \\
\cline { 2 - 8 } & Laves & 12.46 & 20.32 & 33.73 & 5.80 & 1.21 & 26.48 \\
\hline
\end{tabular}


2.2. Mechanical Properties. The true stress-true strain compression curves of the CC and SC hypoeutectic alloys at room temperature are exhibited in Fig. 6. It can be seen that the alloys both have the similar deformation tendency, which exhibits continuous work hardening after the elastic deformation. Clearly, the suction casting increases the yield strength and compressive ductility obviously. Moreover, it can be found that slope of the curve has obvious difference. The slope of the SC hypoeutectic alloy is bigger than that of the CC hypoeutectic alloy. According to the previous research [32], slope of the true stress-true strain is related with the elastic modulus. The higher the slope is, the higher the elastic modulus. Such an evolution may be ascribed to the ultrafine eutectic structure, which could transfer the loading to the $\mathrm{Cr}(\mathrm{Mo})$ and NiAl lamella and take full use of the collaborative deforming. The detailed mechanical properties of the $\mathrm{CC}$ and SC hypoeutectic alloys at $1273 \mathrm{~K}$ and room temperature are presented in Table 2. At room temperature, the SC hypoeutectic alloy obtains yield strength and compressive strength of $1495 \mathrm{MPa}$ and $2030 \mathrm{MPa}$, respectively, which are about 50 and 30\% higher than those of the CC hypoeutectic alloy. The compressive ductility of SC hypoeutectic alloy at room temperature reaches $36 \%$. Compared with the CC hypoeutectic alloy, the SC increases the compressive ductility about $100 \%$. The mechanical properties of the SC hypoeutectic alloy at $1273 \mathrm{~K}$ are a little better than those of the CC hypoeutectic alloy.

$\mathrm{T}$ a b 1 e 2

Compressive Properties of the CC and SC Hypoeutectic Alloys with the Initial Strain Rate of $2 \cdot 10^{-3} \mathrm{~s}^{-1}$

\begin{tabular}{||c|c|c|c|c||}
\hline Alloy & $\begin{array}{c}\text { Test temperature } \\
(\mathrm{K})\end{array}$ & $\begin{array}{c}\text { Yield strength } \\
(\mathrm{MPa})\end{array}$ & $\begin{array}{c}\text { Compressive } \\
\text { strength (MPa) }\end{array}$ & $\begin{array}{c}\text { Compressive } \\
\text { strain (\%) }\end{array}$ \\
\hline \multirow{2}{*}{$\mathrm{CC}$} & $\mathrm{RT}$ & 970 & 1545 & 16 \\
\cline { 2 - 5 } & 1273 & 365 & 410 & $>30$ \\
\hline \multirow{2}{*}{$\mathrm{SC}$} & $\mathrm{RT}$ & 1495 & 2030 & 36 \\
\cline { 2 - 5 } & 1273 & 395 & 465 & $>30$ \\
\hline
\end{tabular}

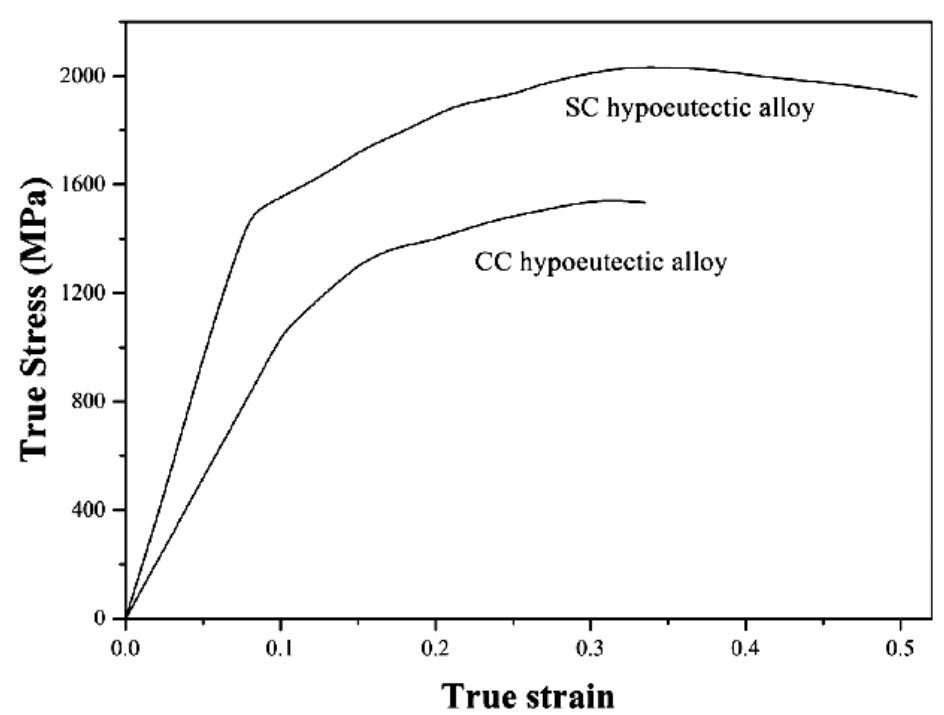

Fig. 6. True stress-true strain compression curves of the CC and SC hypoeutectic alloys at room temperature. 
The typical fracture surfaces of the CC and SC hypoeutectic alloys compressed at room temperature are shown in Fig. 7. Both of them exhibit the brittle fracture characteristic, i.e., typical cleavage in $\mathrm{Cr}(\mathrm{Mo})$ or $\mathrm{NiAl}$ phases and debonding along $\mathrm{NiAl} / \mathrm{Cr}(\mathrm{Mo}$ ) phase interface. The difference is that the CC hypoeutectic alloy mainly exhibits the cleavage along certain crystal plane. Though there are some stages in the cleavage plane, however the propagation of the crack is fast and almost no restriction. Then the cleavage surface shows the river shape. In the fracture surface of the SC hypoeutectic alloy, the cleavage feature could be found on the $\mathrm{Cr}(\mathrm{Mo})$ or NiAl lamella. The debonding feature and crack bridge can be observed in the intercellular region and eutectic cell. Though such features cannot change the main fracture mode, they could handicap the crack propagation and improve the compressive deformation.
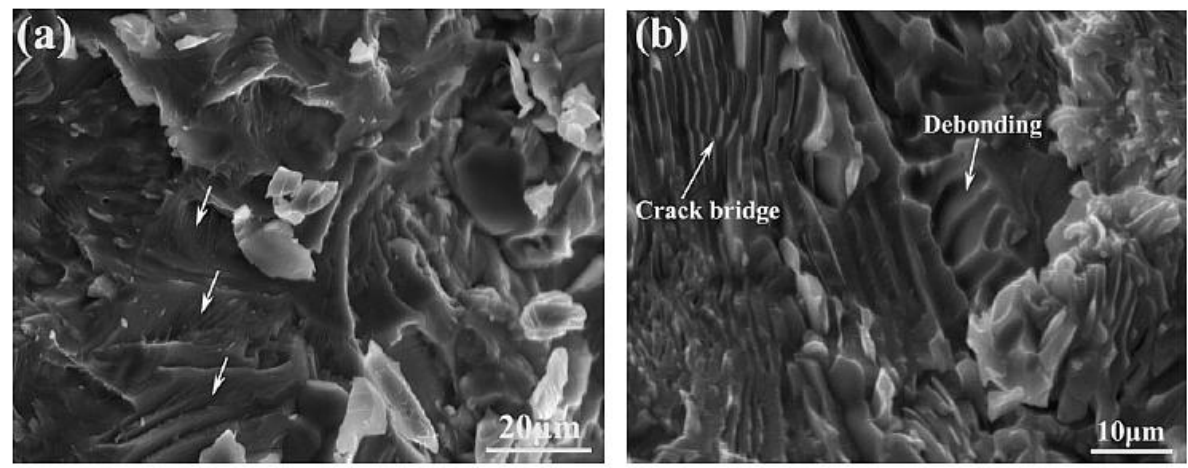

Fig. 7. Typical fracture surface of the $\mathrm{CC}$ and SC hypoeutectic alloys at room temperature: (a) morphology of cleavage in the $\mathrm{CC}$ hypoeutectic alloy (the arrow shows the stages in the cleavage); (b) morphology of debonding, cleavage and crack bridge in the SC hypoeutectic alloy.

The observation on the cross section of the compressive specimen at room temperature is shown in Fig. 8. It can be found that the cracks mainly propagate straightly in the CC hypoeutectic alloy, as shown in Fig. 8a. The $\mathrm{Cr}(\mathrm{Mo})$ or NiAl phase could be traversed by the cracks, which indicates that the $\mathrm{NiAl} / \mathrm{Cr}(\mathrm{Mo})$ eutectic cannot restrict the crack. Then the rapid crack propagation would traverse the whole specimen and result in the failure. The ultrafine $\mathrm{NiAl} / \mathrm{Cr}(\mathrm{Mo})$ eutectic have higher strength, which would resist the propagation of cracks [30]. Therefore, the cracks could not propagate freely and rapidly. The relative weak eutectic cell boundary becomes the main path of the cracks propagation, as shown in Fig. 8b. Due to the tortuous shape of eutectic cell boundary, the cracks have been reflected. Then it would consume more energy to traverse, which is beneficial to the compressive ductility.
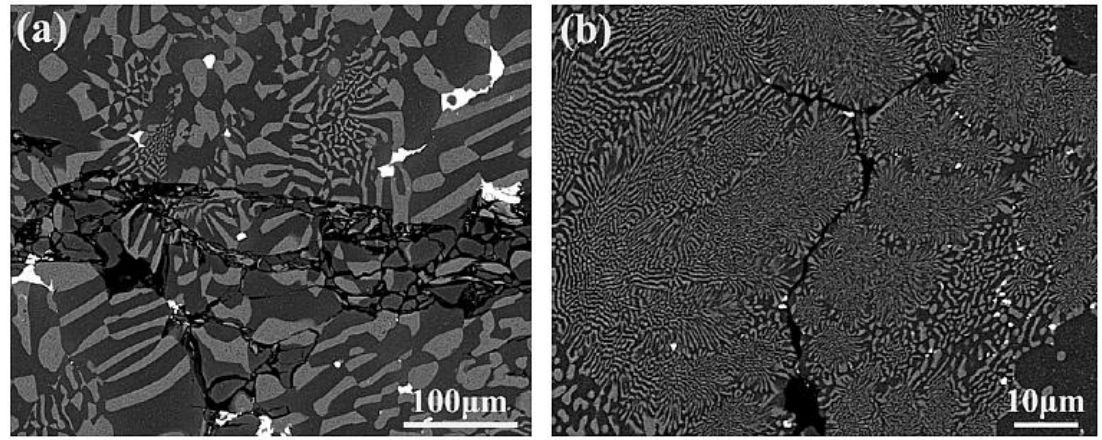

Fig. 8. Morphology of crack propagation in the $\mathrm{CC}$ and $\mathrm{SC}$ alloys at room temperature: (a) $\mathrm{CC}$ hypoeutectic alloy; (b) SC hypoeutectic alloy. 
Based on the above observation, it could be concluded that the improved mechanical properties of the SC hypoeutectic alloy at room and high temperatures should be ascribed to the optimization of microstructure and precipitates. The decrease of lamellar spacing, refinement of eutectic cell and Laves phase, increased area fraction of eutectic cell and extended solid solubility should be the main factors that contributes to the improved ductility and strength of SC hypoeutectic alloy at room temperature. The increase of eutectic cell and decrease of lamellar spacing produce more interfaces between $\mathrm{Cr}(\mathrm{Mo})$ and $\mathrm{NiAl}$ phases. According to former research [33], the interface dislocation network between $\mathrm{Cr}(\mathrm{Mo})$ and NiAl phase could restrict the traverse of mobile dislocations and play an important role in enhancing the strength of $\mathrm{NiAl}$ based alloys. Therefore, more $\mathrm{NiAl} / \mathrm{Cr}(\mathrm{Mo})$ interfaces bring more interface dislocation networks, which would increase the strength of alloy accordingly [34]. The extended solid solubility of alloying elements in $\mathrm{Cr}(\mathrm{Mo})$ and $\mathrm{NiAl}$ is beneficial to the room temperature strength by solution strengthening. Besides, the remarkable increase in the total area of phase or eutectic cell boundaries by SC also promotes an obvious decrease in the segregation concentration of Laves phase, which enhances the particle strengthening effect and improve the strength of alloy. Moreover, the ultrafine $\mathrm{NiAl} / \mathrm{Cr}(\mathrm{Mo})$ eutectic lamella could provide more interface reflecting the cracks, which restricts the rapid propagation of cracks and increase the compressive ductility. Therefore, the improvement of ductility can be ascribed to the fine $\mathrm{NiAl} / \mathrm{Cr}(\mathrm{Mo})$ eutectic structure, as well as the increased area fraction of eutectic cell.

At high temperature, the strength of the SC hypoeutectic alloy is just a little higher than that of the CC hypoeutectic alloy. Such an evolution should be attributed to the softness of the NiAl phase at high temperature. As exhibited in Fig. 9a, the dislocations nucleate near phase boundary and extend in NiAl phase. Moreover the tangled dislocations are also observed in the NiAl phase. However, few dislocations could traverse the phase boundary, which indicates the interface dislocation could restrict the movement of mobile dislocation. The TEM observation on the $\mathrm{Cr}(\mathrm{Mo})$ phase finds fewer dislocations, compared with the NiAl phase. Such phenomenon implies the $\mathrm{Cr}(\mathrm{Mo})$ could resist the deformation at $1273 \mathrm{~K}$. In addition, these dislocations extend to the interface dislocation and terminate, which suggests the interface dislocation would help the improvement of high temperature strength. From this it can be deduced that the ultrafine $\mathrm{Cr}(\mathrm{Mo})$ lamella is beneficial for the high temperature strength, but the NiAl lamella is detrimental. Due to the low bonding strength of intercellular region, the stress concentration along this region would lead to the crack initiation [35]. The increased intercellular region in the SC hypoeutectic alloy would promote the prior deformation and decrease the strength. Therefore, the strengthening effect by the refinement of $\mathrm{NiAl} / \mathrm{Cr}(\mathrm{Mo})$ eutectic is almost counteracted by the intercellular region and primary $\mathrm{NiAl}$ phase.
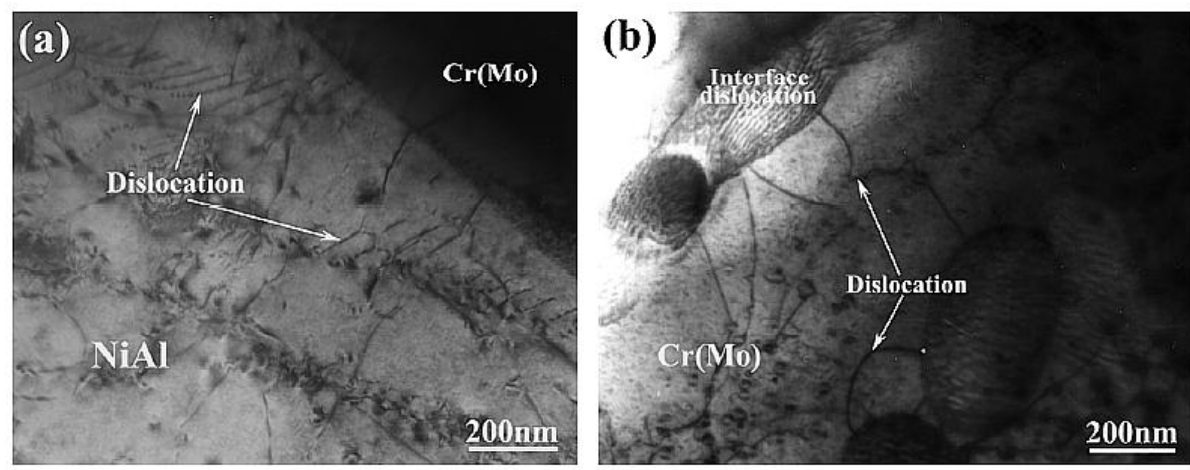

Fig. 9. TEM observation on the SC alloy compressed specimen at $1273 \mathrm{~K}$ : (a) morphology of dislocation in NiAl phase; (b) morphology of dislocation in $\mathrm{Cr}(\mathrm{Mo})$ phase. 
Optimization of Microstructure and Mechanical Properties ...

Conclusions

1. The $\mathrm{NiAl} / \mathrm{Cr}(\mathrm{Mo}, \mathrm{W})-\mathrm{Nb}$ hypoeutectic alloy is prepared by conventional casting, which mainly comprises of coarse primary $\mathrm{NiAl}$ phase and $\mathrm{NiAl} / \mathrm{Cr}(\mathrm{Mo})$ eutectic cell. Minor addition of $\mathrm{Nb}$ results in the precipitation of $\mathrm{Cr}_{2} \mathrm{Nb}$ Laves phase which possesses C14 crystal structure.

2. The suction casting refines the $\mathrm{NiAl} / \mathrm{Cr}(\mathrm{Mo})$ eutectic cell, intercellular region, eutectic lamella and primary $\mathrm{NiAl}$ significantly. Moreover, the distribution of $\mathrm{Cr}_{2} \mathrm{Nb}$ Laves phase becomes uniform in the suction casting alloy. In addition, the suction casting extends the solid solubility.

3. At room temperature, the suction casting hypoeutectic alloy obtains the yield strength and compressive strength of 1495 and $2030 \mathrm{MPa}$, respectively, which are about 50 and $30 \%$ higher than those of the conventional casting hypoeutectic alloy. The compressive ductility of suction casting hypoeutectic alloy at room temperature reaches $36 \%$, which is about two times higher than that of conventional casting hypoeutectic alloy. The significant improvement of the mechanical properties should be attributed to the microstructure refinement by the suction casting.

4. At $1273 \mathrm{~K}$, the suction casting hypoeutectic alloy has the compressive strength of $465 \mathrm{MPa}$ which is somewhat higher than the conventional casting hypoeutectic alloy. The increased interface dislocations by suction casting contribute to the high-temperature strength, but the increased intercellular regions are detrimental to the high-temperature strength.

Acknowledgments. The authors are grateful to the Strategic New Industry Development Special Foundation of Shenzhen (JCYJ20150529162228734, JCYJ20150625155931806, JCYJ20170306141749970，JCYJ20160427100211076，JCYJ20160407090231002，JCYJ 20160329161539885, JCYJ 20160427170611414), and the Shenzhen Technology Innovation Plan (CXZZ20140731091722497 and CXZZ20140419114548507) for financial support.

\section{Резюме}

Получен легированный ниобием $(\mathrm{Nb})$ доэвтектический сплав $\mathrm{NiAl} / \mathrm{Cr}(\mathrm{Mo}, \mathrm{W})$ обычным литьем и литьем методом вакуумного всасывания. Изучены его микроструктура и механические свойства при сжатии для оценки влияния процесса производства. Показано, что крупная первичная фаза $\mathrm{NiAl}$ и эвтектическая ячейка $\mathrm{NiAl} / \mathrm{Cr}(\mathrm{Mo})$ являются основными компонентами сплава $\mathrm{NiAl} / \mathrm{Cr}(\mathrm{Mo}, \mathrm{W})-\mathrm{Nb}$. Введение $\mathrm{Nb}$ способствует образованию фазы Лавеса по границе эвтектической ячейки. Литье методом вакуумного всасывания существенно улучшает состояние эвтектической ячейки $\mathrm{NiAl} / \mathrm{Cr}(\mathrm{Mo})$, первичной фазы NiAl, эвтектической ламеллы, межячеистой области и фазы Лавеса $\mathrm{Cr}_{2} \mathrm{Nb}$, а также обеспечивает равномерное распределение фазы Лавеса $\mathrm{Cr}_{2} \mathrm{Nb}$ и повышает растворимость сплава в твердом состоянии. При комнатной температуре литейный сплав, полученный методом вакуумного всасывания, достигает предела текучести, сопротивления сжатию и пластичности на уровне 1495 МПа, 2030 МПа и 30\% соответственно, что примерно на 50, 30 и 100\% выше аналогичных показателей обычного литейного сплава. Существенное улучшение механических свойств при комнатной температуре может быть обусловлено оптимизацией микроструктуры при литье методом вакуумного всасывания. При 1273 К сплав демонстрирует почти такие же механические свойства, что главным образом связано с увеличением межячеистой области.

1. D. B. Miracle, "Overview No. 104 The physical and mechanical properties of NiAl," Acta Metall. Mater., 41, No. 3, 649-684 (1993). 
2. L. Y. Sheng, F. Yang, T. F. Xi, et al., "Influence of heat treatment on interface of $\mathrm{Cu} / \mathrm{Al}$ bimetal composite fabricated by cold rolling," Compos. Part B - Eng., 42, No. 6, 1468-1473 (2011).

3. L. Y. Sheng, F. Yang, T. F. Xi, et al., "Microstructure evolution and mechanical properties of $\mathrm{Ni}_{3} \mathrm{Al} / \mathrm{Al}_{2} \mathrm{O}_{3}$ composite during self-propagation high-temperature synthesis and hot extrusion," Mater. Sci. Eng. A, 555, 131-138 (2012).

4. L. Y. Sheng, F. Yang, T. F. Xi, and J. T. Gu, "Investigation on microstructure and wear behavior of the NiAl-TiC- $\mathrm{Al}_{2} \mathrm{O}_{3}$ composite fabricated by self-propagation high-temperature synthesis with extrusion," J. Alloy. Compd., 554, 182-188 (2013).

5. B. Zeumer, W. Sanders, and G. Sauthoff, "Deformation behaviour of intermetallic NiAl-Ta alloys with strengthening Laves phase for high-temperature applications IV. Effects of processing," Intermetallics, 7, No. 8, 889-899 (1999).

6. L. Wang, J. Shen, Y. P. Zhang, et al., "Microstructure evolution and room temperature fracture toughness of as-cast and directionally solidified novel NiAl-Cr(Fe) alloy," Intermetallics, 84, 11-19 (2017).

7. R. Darolia, "NiAl alloys for high-temperature structural applications," JOM, 43, No. 3, 44-49 (1991).

8. L. Y. Sheng, "Microstructure and wear properties of the quasi-rapidly solidified NiAl/Cr(Mo,Dy) hypoeutectic alloy," Strength Mater., 48, No. 1, 107-112 (2016).

9. C. Y. Cui, J. T. Guo, and H. Q. Ye, "Microstructure, brittle-ductile transition temperature and elevated temperature compressive behavior of the directionally solidified NiAl-Cr(Mo)-Hf alloy," Mater. Sci. Eng. A, 385, Nos. 1-2, 359-366 (2004).

10. L. Y. Sheng, J. T. Guo, C. Lai, and T. F. Xi, "Effect of Zr addition on microstructure and mechanical properties of NiAl/Cr (Mo) base eutectic alloy," Acta Metall. Sin., 51, No. 7, 828-834 (2015).

11. C. T. Liu and J. A. Horton, Jr., "Effect of refractory alloying additions on mechanical properties of near-stoichiometric NiAl," Mater. Sci. Eng. A, 192-193, 170-178 (1995).

12. B. N. Du, L. Y. Sheng, C. Y. Cui, et al., "Precipitation and evolution of grain boundary boride in a nickel-based superalloy during thermal exposure," Mater. Charact., 128, 109-114 (2017).

13. L. Y. Sheng, F. Yang, J. T. Guo, and T. F. Xi, "Anomalous yield and intermediate temperature brittleness behaviors of directionally solidified nickel-based superalloy," Trans. Nonferr. Met. Soc. China, 24, No. 3, 673-681 (2014).

14. B. H. Han, Y. Ma, H. Peng, et al., "Effect of Mo, Ta, and Re on high-temperature oxidation behavior of minor Hf doped $\beta$-NiAl alloy," Corros. Sci., 102, 222-232 (2016).

15. L. Y. Sheng, F. Yang, J. T. Guo, et al., "Investigation on NiAl-TiC- $\mathrm{Al}_{2} \mathrm{O}_{3}$ composite prepared by self-propagation high temperature synthesis with hot extrusion," Compos. Part B - Eng., 45, No. 1, 785-791 (2013).

16. D. R. Johnson, X. F. Chen, B. F. Oliver, et al., "Processing and mechanical properties of in-situ composites from the NiAl-Cr and the NiAl-(Cr,Mo) eutectic systems," Intermetallics, 3, No. 2, 99-113 (1995).

17. A. A. Zaitsev, Z. A. Sentyurina, E. A. Levashov, et al., "Structure and properties of NiAl-Cr(Co,Hf) alloys prepared by centrifugal SHS casting. Part 1 - Room temperature investigations," Mater. Sci. Eng. A, 690, 463-472 (2017). 
18. L. Y. Sheng, J. T. Guo, T. F. Xi, et al., " $\mathrm{ZrO}_{2}$ strengthened $\mathrm{NiAl} / \mathrm{Cr}$ (Mo, Hf) composite fabricated by powder metallurgy," Prog. Nat. Sci. Mater. Int., 22, No. 3, 231-236 (2012).

19. J. M. Yang, S. M. Jeng, K. Bain, and R. A. Amato, "Microstructure and mechanical behavior of in-situ directional solidified $\mathrm{NiAl} / \mathrm{Cr}(\mathrm{Mo})$ eutectic composite," Acta Mater., 45, No. 1, 295-308 (1997).

20. L. Y. Sheng, F. Yang, T. F. Xi, et al., "Microstructure and elevated temperature tensile behaviour of directionally solidified nickel based superalloy," Mater. Res. Innov., 17, No. S1, 101-106 (2013).

21. C. Y. Cui, J. T. Guo, and H. Q. Ye, "Precipitation behavior of Heusler phase ( $\mathrm{Ni}_{2} \mathrm{AlHf}$ ) in multiphase NiAl alloy," J. Mater. Sci., 41, No. 10, 2981-2987 (2006).

22. L. Y. Sheng, B. N. Du, C. Lai, et al., "Influence of tantalum addition on microstructure and mechanical properties of the NiAl-based eutectic alloy," Strength Mater., 49, No. 1, 109-117 (2017).

23. L. Y. Sheng, "Microstructure, mechanical and tribological properties of the rapidly solidified NiAl/Cr (Mo, Dy) hypoeutectic alloy," Mater. Sci. Forum, 849, 590-598 (2016).

24. L. Y. Sheng, L. Nan, W. Zhang, et al., "Microstructure and mechanical properties determined in compressive tests of quasi-rapidly solidified NiAl-Cr(Mo)-Hf eutectic alloy after hot isostatic pressure and high temperature treatments," J. Mater. Eng. Perform., 19, No. 5, 732-736 (2010).

25. L. Y. Sheng, F. Yang, T. F. Xi, et al., "Improvement of compressive strength and ductility in NiAl-Cr( $\mathrm{Nb} / \mathrm{Dy}$ alloy by rapid solidification and HIP treatment," Intermetallics, 27, 14-20 (2012).

26. W. Zhang, K. Du, X .Q. Chen, et al., "Thermally stable coherent domain boundaries in complex-structured $\mathrm{Cr}_{2} \mathrm{Nb}$ intermetallics," Philos. Mag., 96, No. 1, 58-70 (2016).

27. L. Y. Sheng, W. Zhang, C. Lai, et al., "Microstructure and mechanical properties of Laves phase strengthening NiAl base composite fabricated by rapid solidification," Acta Metall. Sin., 49, No. 11, 1318-1324 (2013).

28. L. Y. Sheng, W. Zhang, J. T. Guo, et al., "Microstructure evolution and elevated temperature compressive properties of a rapidly solidified $\mathrm{NiAl}-\mathrm{Cr}(\mathrm{Nb}) / \mathrm{Dy}$ alloy," Mater. Design, 30, No. 7, 2752-2755 (2009).

29. L. Y. Sheng, W. Zhang, J. T. Guo, et al., "Microstructure evolution and mechanical properties' improvement of NiAl-Cr(Mo)-Hf eutectic alloy during suction casting and subsequent HIP treatment," Intermetallics, 17, 1115-1119 (2009).

30. L. Y. Sheng, J. T. Guo, and H. Q. Ye, "Microstructure and mechanical properties of $\mathrm{NiAl}-\mathrm{Cr}(\mathrm{Mo}) / \mathrm{Nb}$ eutectic alloy prepared by injection-casting," Mater. Design, 30, No. 4, 964-969 (2009).

31. L. Y. Sheng, L. J. Wang, T. F. Xi, et al., "Microstructure, precipitates and compressive properties of various holmium doped $\mathrm{NiAl} / \mathrm{Cr}(\mathrm{Mo}, \mathrm{Hf})$ eutectic alloys," Mater. Design, 32, No. 10, 4810-4817 (2011).

32. L. Y. Sheng, J. T. Guo, Y. X. Tian, et al., "Microstructure and mechanical properties of rapidly solidified NiAl-Cr(Mo) eutectic alloy doped with trace Dy," J. Alloy Compd., 475, Nos. 1-2, 730-734 (2009).

33. M. Probst-Hein, A. Dlouhy, and G. Eggeler, "Interface dislocations in superalloy single crystal," Acta Mater., 47, No. 8, 2497-2510 (1999). 
34. L. Y. Sheng, J. T. Guo, L. Z. Zhou, and H. Q. Ye, "Microstructure and compressive properties of NiAl-Cr(Mo)-Dy near eutectic alloy prepared by suction casting," Mater. Sci. Tech., 26, No. 2, 164-168 (2010).

35. L. Y. Sheng, J. T. Guo, W. Zhang, et al., "Microstructure and mechanical properties of NiAl-Cr(Mo)-Hf/Ho near-eutectic alloy prepared by suction casting," Int. J. Mater. Res., 100, No. 11, 1602-1606 (2009).

Received 15. 09. 2017 